\title{
Meningkatkan Keterampilan Berbicara Menggunakan Metode Contextual Teaching and Learning Siswa Kelas XI SMK BSI
}

\author{
Putu Intan Kurnia \& Waspodo \\ Program Pascasarjana Universitas Bina Darma \\ Email: putupsikologi@gmail..com
}

\begin{abstract}
The purpose of this Internship research aims to analyze: 1). speaking skills of XI Tourism Hospitality class students. 2). learning using the Contextual Teaching and Learning method which is carried out in class XI Hospitality Tourism so that students have good and correct Indonesian language skills. 3). how to improve students' speaking ability after the lesson using the Contextual Teaching and Learning method.Qualitative methods are used in the research approach undertaken. Where this qualitative research seeks to provide an explanation, describe, and outline the main issues that will be discussed in the study then draw conclusions deductively. Based on the results of the study indicate that the object of research is a number of 15 students of this study from pre-cycle to cycle 1 shows that there is an increase in the average value of students that is 64.33 to 73.67. While from pre-cycle to cycle 2 shows that there is an increase in the average value of students that is 64.33 to 78. From the results above indicate that there has been a change from pre-cycle to cycles 1 and 2. These conditions indicate that there has been a change the value of students who showed an increase in students' abilities since using the CTL method. So from here it shows that the application of the CTL method has a good impact on improving students' ability to speak.
\end{abstract}

Keywords: speaking skills, improvement, contextual teaching and learning

\section{Pendahuluan}

Keterampilan berbicara merupakan salah satu dari empat keterampilan berbahasa.Keempat keterampilan berbahasa meliputi menyimak, berbicara, membaca, dan menulis. Sehingga berbicara harus di maksimalkan untuk meningkatkan kemampuan berbahasa sehingga dapat berkomunikasi atau menyampaikan ide, gagasan maupun pemikiran dengan orang lain. Kasbiyono (2012). Dengan kemampuan berbicara ini maka seseorang akan dapat menyampaikan pemikirannya dalam bentuk suara.

Salah satu bentuk dari ketrampilan mekanistis adalah ketrampilan berbicara.Semakin banyak berlatih berbicara, semakin dikuasai keterampilan berbicara, maka dari itu tidak ada orang yang langsung terampil berbicara tanpa melalui proses latihan. Ketrampilan bicara tersebut akan memudahkan seseorang untuk menyampaikan pemikirannya secara sistematis dan terstruktur. Sehingga akan lebih mudah dalam berkomunikasi sebab apa yang disampaikannya mudah di pahami oleh pendengarnya. Hal ini menunjukkan bahwa berlatih bicara yang dilakukan secara intensif dapat meningkatkan ketrampian berbicara, dan seseorang tidak akan angsung terampil berbicara jika tidak melakukan latihan-latihan. Kundharu Saddhono dan Slamet (2012).

Published by

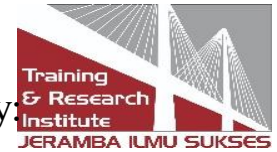


Dalam meningkakan ketrampilan berbicara siswa maka diperlukan proses pembelajaran yang bervariasi sesuai dengan orientasi pendidikan yang diciptakan. Pada kegiatan pengajaran yang ada pada system tradisional potensi siswa berbicara relatif terhambat, sehingga masih banyak siswa yang belum mempunyai ketrampilan berbicara yang baik.Dengan kondisi ini maka harus ada perubahan strategi yang dilakukan oleh guru dalam meningkatkan kemampuan berbicara siswa. Perubahan ini di harapkan dapat membantu siswa dalam meakukan proses pembelajaran. Selaian itu, dengan upaya yang sesuai dapat meningkatkan keterampilan siswa tersebut dalam belajar dan dapat mneingkatkan prestasi siswa.Berdasarkan observasi lapangan di Sekolah Menengah Kejuruan Bina Sriwijaya Palembang menunjukkan bahwa banyak siswa tertutama Siswa Kelas XI Pariwisata Perhotelan kurang atau tidak aktif dalam proses pembelajaran sehingga terdapat beberapa siswa yang belum bisa berbicara dengan baik, dan kurangnya perhatian orang tua dan guru dalam mendorong siswa untuk belajar. Kondisi ini akan mempengaruhi keberhasilan siswa dalam mengikuti proses belajar mengajar. Sehingga akan membuat siswa tidak mampu menguasai secara optimal materi yang diberikan. Kondisi Siswa Kelas XI Pariwisata Perhotelan menunjukkan kurangnya motivasi yang kurang dari siswa dalam mengikut proses pembelajara yang dilakukan sehingga mengakibatkan kemampuan siswa dalam berbahasa menjadi rendah. Dari hasil data awal yang di dapat menunjukkan bahwa nilai rata-rata nili siswa dalam berbahasa hanya 64,33 sehingga maih belum mencapai nilai KKM.Berpedoman pada pada latar belakang yang ada maka peneliti mencoba untuk menggali memanfaatkan metode CTL untuk meningkatkan keterampilan berbicara oleh karena itu kasus sebagai berikut "Meningkatkan keterampilan berbicara menggunakan metode Contextual Theaching and Learning Siswa Kelas XI Pariwisata Perhotelan

\section{Tinjauan Literatur}

Prasetyani (2010) dengan judul Peningkatan Hasil Belajar Dengan Menggunakan Metode Pembelajaran SQ4R (Survey, Question, Read, Reflect,Recite, Review) Melalui Pendekatan Talking Stick Pada Mata Pelajaran Biologi Kelas XI Pokok Bahasan Sistem Peredaran Darah Di SMA Negei 31Semarang pada penelitian tersebut menunjukkan Hasil penelitian pada hasil siklus I persentase keaktifan siswa sebesar $50 \%$ dan nilai rata-rata kelas baru mencapai Nilai rata- rata kelas $(65,79)$ nilai ketuntasan belajar klasikal $(47,37)$, nilai ketuntasan belajar individu $(66,67)$, kemudian pada siklus II persentase keaktifan siswa $75 \%$ dan nilai rata-rata meningkat menjadi $(71,40)$ nilai ketuntasan belajar klasikal $(55,26)$, nilai ketuntasan belajar individu $(80,00)$, dan pada siklus III persentase keaktifan siswa $95 \%$ dan nilai rata-rata kelas $(74,21)$ nilai ketuntasan belajar klasikal $(76,32)$, nilai ketuntasan belajar individu $(80,00)$.Persamaan penelitian ini dengan dengan penelitian yang akan dikembangkan adalah sama-sama menggunakan pendekatan talking stick.

Septiyani (2011) dengan judul Penerapan model talking stick untuk meningkatkan hasil belajar siswa pada mata pelajaran Bahasa Indonesia kelas V SDN Tanjungrejo 2 Malang pada penelitian tersebut menujukkan Hasil penelitian menunjukkan bahwa penerapan model talking stick pada pembelajaran Bahasa Indonesia telah berhasil meningkatkan hasil belajar siswa kelas V SDN Tanjungrejo 2 Malang. Hal ini dilihat dari perolehan rata-rata hasil belajar siswa yang terus meningkat, mulai dari nilai rata-rata sebelumnya (62) mengalami peningkatan pada siklus I dengan nilai rata-rata kelas sebesar (66) dan persentase ketuntasan belajar kelasnya yaitu (50\%) meningkat pada siklus II dengan nilai rata-rata kelasnya sebesar (80) dan persentase ketuntasan belajar kelasnya sebesar (93\%). Aktivitas belajar siswa juga mengalami

Published by

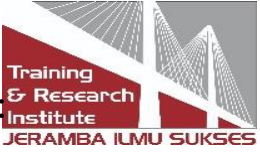


peningkatan pada siklus I pertemuan 1 dengan nilai rata-rata kelas sebesar (64), meningkat pada siklus I pertemuan 2 dengan nilai rata-rata sebesar(69), meningkat pada siklus II pertemuan 1 dengan nilai rata-rata sebesar (78). Persamaan penelitian ini dengan dengan penelitian yang akan dikembangkan adalah sama-sama menggunakan model talking stick dan pada mata pelajaran Bahasa Indonesia

\section{Metode Penelitian}

Peneliatian ini adalah penelitian kualitatif yang penelitiannya berusaha untuk memamparkan pemecahan masalah untuk dijadikan rujukan berupa data data yang ada, peneliti juga menyajikan data, menganalisis dan menginterprestasikan yang bersifat komperatif dan korelatif (Fauzi, Dencik, \& Asiati, 2019). Dalam penelitian kualitatif ini tidak terdapat pengujian statistik.Data-data yang dianalisis selanjutnya di intepretasikan dengan membandingkan dengan teori-teori yang ada. Dalam penelitian ini data-data yang di olah merupakan data-data siswa kelas XI meliputi proses pembelajaran, nilai siswa, kurikulum mata pembelajaran dan wawancara. Analisis data yaitu proses mencari dan menyusun data yang di peroleh dari hasil wawancara, observasi, dan dokumentasi secara sistematis sehingga mudah di pahami dan temuannya tersebut akan di sampaikan kepada pihak yang terkait. Untuk menentukan upaya apa yang akan dilakukan untuk meningkatkan keterampilan berbicara siswa maka didalam penelitian ini menggunakan penelitian tindakan kelas.

\section{Hasil dan Pembahasan}

\subsection{Analisis Kasus}

Tabel 1. Hasil Test Pra Siklus Peserta Didik Sebelum Penerapan Metode Contextual Theaching and Learning( CTL) pada Kelas XI

\begin{tabular}{|l|l|c|}
\hline No & \multicolumn{1}{|c|}{ Nama Siswa } & Nilai \\
\hline 1 & AM & 60 \\
\hline 2 & AMM & 70 \\
\hline 3 & CGK & 75 \\
\hline 4 & CJ & 70 \\
\hline 5 & DA & 60 \\
\hline 6 & I & 65 \\
\hline 7 & MAT & 60 \\
\hline 8 & M R & 60 \\
\hline 9 & N S & 60 \\
\hline 10 & R & 65 \\
\hline 11 & S A S & 70 \\
\hline 12 & T & 65 \\
\hline 13 & T S & 60 \\
\hline 14 & Y & 60 \\
\hline 15 & S & 65 \\
\hline & Rata-rata & 64,33 \\
\hline
\end{tabular}


Jika dilhat dari tabel di atas menunjukkan bahwa nilai peserta didik untuk kemampuan bicara pada saat belum di berlakukan metode contextual theaching and learning (CTL) kebanyakan mempunyai nilai $>=70$ dimana nilai tersebut di dapat oleh 12 orang peserta didik, sedangkan nilai kurang dari 70 ada 3 orang peserta didik. Pada table tersebut menunjukka nilai 60 lebih dari 50\%, sehingga menunjukkan bahwa kemampuan bicara siswa relative rendah. Jika dilihat table 2 menunjukkan bahwa nilai rata-rata meningat jadi 73,67. Kondisi ini diakibatkan karena penerapan metode CTL mulai dilakukan. Dari hasil tersebut kita bandingkan antara sebelum dan sesudah penerapan metode contextual theaching and learning (CTL) yang dapat dilihat pada table di bawah ini :

Tabel . Hasil Test Siklus Pertama Peserta Didik Setelah Penerapan Metode Contextual Theaching and Learning ( CTL) pada Kelas XI

\begin{tabular}{|l|l|c|}
\hline No & \multicolumn{1}{|c|}{ Nama Siswa } & Nilai \\
\hline 1 & AM & 65 \\
\hline 2 & A M M & 70 \\
\hline 3 & C G K & 80 \\
\hline 4 & C J & 75 \\
\hline 5 & D A & 75 \\
\hline 6 & I & 65 \\
\hline 7 & M A T & 80 \\
\hline 8 & M R & 85 \\
\hline 9 & N S & 75 \\
\hline 10 & R & 70 \\
\hline 11 & S A S & 80 \\
\hline 12 & T & 75 \\
\hline 13 & T S & 75 \\
\hline 14 & Y & 70 \\
\hline 15 & S & 65 \\
\hline & Rata-rata & 73,67 \\
\hline
\end{tabular}

Dari tabel di atas menunjukkan bahwa sebagian besar peserta didik mengalami peningkatan pada hasil test siklus setelah menggunakan metode contextual theaching and learning (CTL). Hasil peningkatan ini ditunjukkan dari meningkatnya nilai rata-rata nilai peserta didik dari 64,33 menjadi 73,67 dimana hampir seluruh peserta didik mengalami peningkatan dalam nilai. Kondisi ini menunjukkan bahwa peserta didik mengalami peningkatan kemampuan berbicara dalam etika komunikasi telepon.Peningkatan ini sudah menunjukkan bahwa penerapan metode CTL ini memberikan dampak yang cukup baik walaupun belum keseluruhan siswa dapat mengikutinya.Untuk itu perlu adanya perbaikan lagi atau pengenalan lagi bagi siswa agar mereka tertarik untuk mengikutinya.Perbaikan ini diperlukan untuk memaksimalkan metode CTL ini sehingga bisa berdampak pada perbaikan ketrampilan bicara siswa. 
Tabel 3. Hasil Test Siklus Kedua Peserta Didik Setelah Penerapan Metode Contextual Theaching and Learning ( CTL) pada Kelas XI

\begin{tabular}{|l|l|c|}
\hline No & \multicolumn{1}{|c|}{ Nama Siswa } & Nilai \\
\hline 1 & AM & 70 \\
\hline 2 & A M M & 85 \\
\hline 3 & C G K & 80 \\
\hline 4 & C J & 80 \\
\hline 5 & D A & 75 \\
\hline 6 & I & 80 \\
\hline 7 & M A T & 80 \\
\hline 8 & M R & 85 \\
\hline 9 & N S & 75 \\
\hline 10 & R & 70 \\
\hline 11 & S A S & 80 \\
\hline 12 & T & 75 \\
\hline 13 & T S & 85 \\
\hline 14 & Y & 70 \\
\hline 15 & S & 80 \\
\hline & Rata-rata & 78,00 \\
\hline
\end{tabular}

Dari tabel di atas menunjukkan bahwa sebagian besar peserta didik mengalami peningkatan pada hasil test siklus 2 setelah menggunakan perbaikan metode contextual theaching and learning (CTL). Hasil peningkatan ini ditunjukkan dari meningkatnya nilai rata-rata nilai peserta didik dari 64,33 menjadi 73,67 selanjutnya menjadi 78,00 dimana seluruh peserta didik mengalami peningkatan dalam nilai. Kondisi ini menunjukkan bahwa peserta didik mengalami peningkatan kemampuan berbicara dalam etika komunikasi telepon.Pada siklus kedua menunjukkan bahwa siswa mulai beradaptasi terhadap metode CLT ini.Dimana ditunjukkannya peningkatan pada seluruh siswa. Siswa mulai termotivasi untuk mengikuti proses belajar mengajar. Dengan semakin termotivasinya siswa maka akan lebih memudahkan proses pembelajaran CTL ini. 
Tabel 4. Hasil Test Siklus Peserta Didik Setelah Melaukan Perngukuran Penerapan Metode Contextual Theaching and Learning ( CTL) pada Kelas XI

\begin{tabular}{|l|l|c|c|c|c|c|}
\hline No & $\begin{array}{l}\text { Nama } \\
\text { Siswa }\end{array}$ & $\begin{array}{c}\text { Nilai } \\
\text { Sebelum }\end{array}$ & $\begin{array}{c}\text { Nilai } \\
\text { Sesudah } \\
\text { (Siklus 1) }\end{array}$ & $\begin{array}{c}\text { Persentase } \\
\text { Perubahan }\end{array}$ & $\begin{array}{c}\text { Nilai } \\
\text { Sesudah } \\
\text { (Siklus 2) }\end{array}$ & $\begin{array}{c}\text { Persentase } \\
\text { Perubaha } \\
\text { n }\end{array}$ \\
\hline 1 & AM & 60 & 65 & $8 \%$ & 70 & $16 \%$ \\
\hline 2 & A M M & 70 & 70 & $0 \%$ & 85 & $21 \%$ \\
\hline 3 & C G K & 75 & 80 & $6 \%$ & 80 & $6 . \%$ \\
\hline 4 & C J & 70 & 75 & $7 \%$ & 80 & $14 \%$ \\
\hline 5 & D A & 60 & 75 & $25 \%$ & 75 & $25 \%$ \\
\hline 6 & I & 65 & 65 & $0 \%$ & 80 & $23 \%$ \\
\hline 7 & M A T & 60 & 80 & $33 \%$ & 80 & $33 \%$ \\
\hline 8 & M R & 60 & 85 & $41 \%$ & 85 & $41 \%$ \\
\hline 9 & N S & 60 & 75 & $25 \%$ & 75 & $25 \%$ \\
\hline 10 & R & 65 & 70 & $7 \%$ & 70 & $7 \%$ \\
\hline 11 & S A S & 70 & 80 & $14 \%$ & 80 & $14 \%$ \\
\hline 12 & T & 65 & 75 & $15 \%$ & 75 & $15 \%$ \\
\hline 13 & T S & 60 & 75 & $25 \%$ & 85 & $41.67 \%$ \\
\hline 14 & Y & 60 & 70 & $16 \%$ & 70 & $16.67 \%$ \\
\hline 15 & S & 65 & 65 & $0 \%$ & 80 & $23 \%$ \\
\hline \multicolumn{2}{|l|}{ Rata-rata } & 64.33 & 73.67 & & 78.00 & \\
\hline
\end{tabular}

Pada tabel di atas menunjukkan bahwa dari pra siklus ke siklus 1 menunjukkan bahwa ada peningkatan dalam rata-rata nilai siswa yaitu 64,33 menjadi 73,67 . Pada pra siklus nilai tertinggi adalah 75 sedangkan nilai terendah adalah 60.Sedangkan pada siklus 1 terjadi peningkatan niai tertinggi yaitu 80 sedangkan nilai terendah 65.Berarti terjadi peningkatan dari pra siklus ke siklus 1 , tetapi tidak keseluruhan terjadi kenaikan pada siswa masih terdapat 3 orang siswa yang tidak naik nilainya.Persentase perubahan tertinggi dari pra siklus ke siklus 1 adalah 33\% sedangkan perubahan terendah adalah $0 \%$.Dari hasil perhitungan pada table 4 menunjukkan semua siswa mengalami peningkatan dalam nilainya sehingga dari table ini menunjukkan bahwa penerapan metode CTL ini membawa perubahan pada kemampuan dan ketrampilan siswa dalam berbicara.Untuk itu makan guru bisa melanjutkan penerapan metode ini sehingga memberikan ketrampilan bicara yang mumpuni dan oleh siswa bisa dilaksanakan dalam kegiatan kehidupannya sehari-hari. Dengan menerapkannya pada kebiasaan yang dilakukan secara rutin setiap harinya siswa akan lebih mudah memahami materi-materi belajar yang diberikan oleh guru.

\subsection{Pembahasan}

Pada tabel di atas menunjukkan bahwa dari pra siklus ke siklus 1 menunjukkan bahwa ada peningkatan dalam rata-rata nilai siswa yaitu 64,33 menjadi 73,67 . Pada pra siklus nilai

Published by

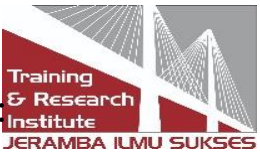


tertinggi adalah 75 sedangkan nilai terendah adalah 60.Sedangkan pada siklus 1 terjadi peningkatan niai tertinggi yaitu 80 sedangkan nilai terendah 65.Perhitungan tersebut menunjukkan bahwa ada perubahan yang cukup baik dari pra siklus ke siklus 1, tetapi tidak keseluruhan terjadi kenaikan pada siswa masih terdapat 3 orang siswa yang tidak naik nilainya.Persentase perubahan tertinggi dari pra siklus ke siklus 1 adalah 33\% sedangkan perubahan terendah adalah $0 \%$.

Pada tabel di atas menunjukkan bahwa dari pra siklus ke siklus 2 menunjukkan bahwa ada peningkatan dalam rata-rata nilai siswa yaitu 64,33 menjadi 78 . Pada pra siklus nilai tertinggi adalah 75 sedangkan nilai terendah adalah 60.Sedangkan pada siklus 2 terjadi peningkatan niai tertinggi yaitu 85 sedangkan nilai terendah 70. Perhitungan tersebut menunjukkan bahwa ada perubahan yang cukup baik dari pra siklus ke siklus 2, dan secara keseluruhan terjadi kenaikan pada siswa. Persentase perubahan tertinggi dari pra siklus ke siklus 2 adalah 41,67\% sedangkan perubahan terendah adalah $7 \%$.

Selanjutnya kenaikan persenase nilai siswa akan di bagi menjadi 3 tingkatan yaitu :

- Kenaikan nilai $<10 \%$ berarti rendah

- Kenaikan nilai 10\% - 30 berarti sedang

- Kenaikan nilai $>30 \%$ berarti tinggi

Berdasarkan hasil siklus 1 menunjukkan bahwa :

- Kenaikan nilai $<10 \%$ berarti rendah, terdapat 7 orang siswa yang kenaikannya rendah, bahkan terdapat siswa yang yang kenaikan nilainya $0 \%$

- Kenaikan nilai 10\% - 30 berarti sedang, terdapat 6 orang siswa yang kenaikannya sedang

- Kenaikan nilai $>30 \%$ berarti tinggi, terdapat 2 orang siswa yang kenaikannya tinggi.

Selanjutnya dilakukan wawancara terhadap siswa yang mempunyai kenaikan nilai termasuk tingkatan rendah di dapat bahwa mereka belum dapat menyesuaikan metode pembelajaran yang baru dan belum merasa termotivasi untuk meningkatka kemampuan mereka Sedangkan wawancara yang dilakukan terhadap siswa yang mempunyai kenaikan nilai termasuk tingkatan sedang di dapat bahwa mereka sedikit termotivasi tetapi masih belum terlalu dapat meyesuaikan metode pembelajaran yang baru, sehingga belum dapat meningkatkan secara maksimal kemampuan mereka.

Sedangkan wawancara yang dilakukan terhadap siswa yang mempunyai kenaikan nilai termasuk tingkatan tinggi di dapat bahwa mereka sangat termotivasi untuk mengikuti maa pelajaran ini dengan metode CTL sebab mereka dapat mengubungkannya dengan kondisi mereka sehari-hari sehingga hasil yang didapat adalah lebih maksimal dalam meningkatkan kemampuan berbahasanya.

Selanjutnya untuk memperbaiki metode yang di coba pada siklus 1 maka dilakukan pada siklus 2. Hasil yang di dapat adalah sebagai berikut : Kenaikan nilai $<10 \%$ berarti rendah, terdapat 2 orang siswa yang kenaikannya rendah, siswa ini pada siklus 1 juga berada pada tingkatan rendah.

- Kenaikan nilai 10\% - 30 berarti sedang, terdapat 9 orang siswa yang kenaikannya sedang

Published by

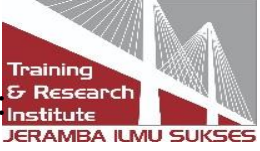


- Kenaikan nilai $>30 \%$ berarti tinggi, terdapat 5 orang siswa yang kenaikannya tinggi.

- Dari hasil tersebut maka perlunya perbaikan-perbaikan dalam metode penyampaian materi pelajaran yang menggunakan metode CTL ini sehingga siswa akan lebih tertarik dan antusias untuk mengikuti pelajaran ini. Guru juga diharapkan dapat melakukan variasivariasi dalam pemberian materi ajar sehingga siswa tidak bosan. Selain itu juga guru juga sebaiknya harus benar-benar mengetahui karakteristik siswa yang di ajarnya sehingga dapat memberikan materi yang akan mudah di mengerti oleh siswa dan membangkitkan gairah siswa untuk mengikuti mata pelajaran ini. Meningkatnya motivasi siswa ini akan memberikan dampak bagi siswa dalam proses belajar mengajar, siswa menjadi semangat sehingga pemberian materi oleh guru menjadi lebih mudah untuk diterima rumah.

\section{Kesimpulan}

Penelitian di atas memberikan bebarapa hasil yang dapat disimpukan sebagai berikut (1) 1 . Kemampuan berbicara siswa kelas XI Pariwisata Perhotelan sebelum penerapan metode CTL relative rendah ini ditunjukkan dengan nilai rata-rata 64,33 sedangkan nilai terendah adalah 60 dan nilai tertinggi 75 . Kondisi ini menunjukkan bahwa siswa belum termotivasi untuk mengikuti pelajaran pada metode lama, sehingga ketrampilannya rendah; (2) 2. Pelaksanaan CL meliputi pengembangan pola pikir anak bahwa mereka akan belajar lebih bermakna dengan cara bekerja sendiri, menemukan sendiri, dan mengkonstruksi sendiri pengetahuan dan keterampilan barunya. Tahapan selanjutnya guru membuat kelompok-kelompok belajar siswa untuk membahas materi yng diajarkan. Selanjutnya guru membuat pertanyaan untuk membuat penilaian secara kontinyu terhadap pemahaman siswa. Tahapan selanjutnya siswa saling mengisi, semua siswa di harapkan aktif dalam melakukan diskusi kelompok tanpa memandang siswa tersebut pandai atau tidak. Siswa di ajarkan untuk saling menghargai pendapat orang lain dan belajar untuk mengemukakan ide atau pemikirannya. Tahapan terakhir yaitu refleksi merupakan gambaran terhadap kegiatan atau pengetahuan yang baru saja diterima. Segala sesuatu pengetahuan yang baru harus disimpan dalam memori pemikirannya, yang merupakan struktur pengetahuan yang baru dan merupakan pengayaan atau revisi dari pengetahuan sebelumnya. Untuk itu perlu adanya suatu analisis terhadap pengetahuan sebelumnya sehingga dapat diperbaiki dan ditingkatkan kualitasnya; (3) 3.Berdasarkan hasil penelitian menunjukkan bahwa dari pra siklus ke siklus 1 menunjukkan bahwa ada peningkatan dalam rata-rata nilai siswa yaitu 64,33 menjadi 73,67. Sedangkan dari pra siklus ke siklus 2 menunjukkan bahwa ada peningkatan dalam rata-rata nilai siswa yaitu 64,33 menjadi 78 . Pada penelitian tersebut menunjukkan bahwa bahwa perubahan telah terjadi yaitu dari pra siklus ke siklus 1 dan 2 . Kondisi ini menunjukkan bahwa telah terjadi perubahan nilai siswa yang menunjukkan peningkatan kemampuan siswa sejak menggunakan metode CTL. Sehingga dari sini menunjukkan bahwa penerapan metode CTL memberikan dampak yang baik bagi peningkatan kemampuan siswa dalam berbicara.

\section{Referensi}

Anwar. (2008). Upaya Meningkatkan Belajar Siswa pada Pembelajaran Matematika melalui Pendekatan Contextual Teaching and Learning (Skripsi S-1 Progdi Pendidikan Matematika) Surakarta: FKIP Universitas Muhammadiyah Surakarta. 
Arikunto. (2015). Penelitian Tindakan Kelas (Edisi Revisi). Jakarta.Bumi Aksara

Arikunto, S. (2010). Prosedur Penelitian, Suatu Pendekatan Praktik Edisi Revisi 2010. Jakarta: Rhineka Cipta.

Ahmadi, A. (1977). Dasar-Dasar Praktek Mengajar. CV Toha Putra. Semarang.

Azizah, N. (2013). Tingkat keterampilan berbicara di tinjau dari metode bermain peran pada anak usia 5-6 tahun. Indonesia Journal off Early Childhood Education Studies, 2.

Annur, S. (2008). Metodelogi Penelitian Pendidikan (Analisis Data Kualitatif dan kuantitatif) Palembang: Grafika Telindo Press

Ari Sutrisno. (2010). Meningkatkan keterampilan menulis karangan deskripsi pada siswa kelas IVA SDN Dukuhan Kerten melalui pendekatan Contextual Teaching and Learning (CTL).

Anna Astiningtyas. (2019). Upaya Peningkatan Keterampilan Berbicara Melalui PS- MTTW dalam Pembelajaran Tematik Terpadu Kelas IV SD.

Bartjan. (2016). Metodologi Penelitian Panduan Untuk Mater dan Ph.D di Bidang Manajemen. Jakarta:.Salemba Empat

Buchory, MS. (2016). Prosiding Seminar Nasional Univeristas PGRI Yogyakarta.Journal

Depdiknas. (2003). Undang-Undang Sistem Pendidikan Nasional. Jakarta: Departemen

Pendidikan Nasional.

Depdiknas. (2006). Permendiknas No 22 Tahun 2006 Tentang Standar Isi.Jakarta : Depdiknas. Fitri.2018. meningkatkan keterampilan berbicara anak kelompok B di TK Pertiwi Kedungupit Sragen tahun ajaran 2017/2018 ("'Skripsi S-1 Progdi Pendidikan guru pendidikan usia dini dan ilmu pendidikan). Surakarta.

Fauzi, F., Dencik, A. B., \& Asiati, D. I. (2019). Metodologi Penelitian Untuk Manajemen dan AKuntansi. Jakarta: Salemba Empat.

Johnson, Elaine B. (2002). Contextual Teaching \& Learning. Bandung: Kaifa

Prasetyani. (2010). Peningkatan Hasil Belajar Dengan Menggunakan Metode Pembelajaran SQ4R (Survey, Question, Read, Reflect, Recite, Review) Melalui Pendekatan Talking Stick Pada Mata Pelajaran Biologi Kelas XI Pokok Bahasan Sistem Peredaran Darah Di SMA Negeri 31Semarang

Kasbiyono. (2019). Upaya Peningkatan keterampilan berbicara melalui PS-MTTW dalam pembelajaran tematik terpadu kelas IV SD. Jurnal.Salatiga

Sudjana. (1996), Cara belajar siswa aktif dalam proses belajar mengajar. Bandung: Sinar Baru Algensindo

Septiyani. (2011). Penerapan model talking stick untuk meningkatkan hasil belajar siswa pada mata pelajaran Bahasa Indonesia kelas V SDN Tanjungrejo 2 Malang

Sugiyono. (2009). Metode penelitian Pendidikan (Pendekatan Kualitatif dan R\&D. Bandung : Alfabeta

Sugiyono. (2009). Metode Penelitian Pendidikan (Pendidikan Tindakan Kelas). Bandung : Alfabeta

Saddhono dan Slamet. (2012). Meningkatkan Keterampilan Berbahasa Indonesia (Teori dan Aplikasi). Bandung: Karya Putra

Sanjaya, W. (2010). Starategi pembelajaran berorientasi standar proses pendidikan.

Published by

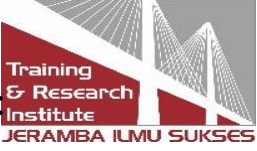


Jakarta. Prenada Media Grup.

Sanjaya, W. (2009). Stategi Pembelajaran Berorientasi Standar Proses Pendidikan. Jakarta: Kencana.

Sugiyanto. (2007). Model-model Pembelajaran Inovatif. Surakarta:Panitia Sertifikasi Guru Rayon 13.

Sugiyono. (2015). Metodologi Penelitian Pendidikan Pendekatan Kuantitatif, Kualitatif,dan R\&D. Bandung: Alfabeta

Sugiyono. (2013). Metodelogi Penelitian Pendidikan Pendekatan Kuantitatif, Kualitatif dan R\&D. Bandung: Alfabeta

Shabir. (2015). Kedudukan Guru Sebagai Pendidik. Jurnal.Makassar

Supriyadi dkk. (1991). Pendidikan Bahasa Indonesia 2. (Jakarta: Depdikbud)

Sanusi. (2015). Pendidikan Profesi Keguruan Menjadi Guru Inspiratif dan Inovatif.Bandung. Pustaka Setia

Sani. (2014). Inovasi Pembelajaran.Jakarta.Bumi Aksara

Sri Indriati. (2018). Front Office Bidang Keahilan Pariwisata Program Keahlian Perhotelan dan jasa Pariwisata Kompetensi Keahlian : Hotel dan Restoran Kelas X/XI SMK.Yogyakarta. ANDI

Sri Indriati. (2018). Front Office Bidang Keahilan Pariwisata Program Keahlian Perhotelan dan jasa Pariwisata Kompetensi Keahlian : Hotel dan Restoran Kelas XII SMK.Yogyakarta. ANDI

Sri Widarti. (2013). Pembelajaran Galery Walk Berpendekatan Contextual Teaching and Learning Materi Sistem Pencernaan di SMA.

Tarigan Henry, Guntur. (2008). berbahasa sebagai sesuatu keterampila berbahasa.Bandung: Angkasa

Undang- undang No .20 Tahun 2003 tentang Sistem Pendidikan Nasional (Sisdiknas).

http://filediamant.wordpress.com/2013/03/18/65-model-pembelajaran-dan-15-metodepembelajaran.Diakses Minggu 12 Mei 2013

https://www.academia.edu/9282428/EMPAT_Aspek_Keterampailan_Berbahasa

Diakses pada tanggal Selasa, 16 Juli 2010

\section{Copyrights}

Copyright for this article is retained by the author(s), with first publication rights granted to the journal.

This is an open-access article distributed under the terms and conditions of the Creative Commons Attribution license (http://creativecommons.org/licenses/by/4.0/) 